\title{
Para além da ordem: o cotidiano prisional da Bahia oitocentista a partir da correspondência de presos
}

Cláudia Moraes TRINDADE*

\begin{abstract}
Resumo: Este artigo tem o objetivo de discutir a comunidade prisional na Bahia Oitocentista, a partir das correspondências de presos. Faço uma análise dessa documentação buscando reconstruir parte do cotidiano dos presos, pressupondo a existência de uma ordem paralela, com igual ou maior força do que a oficial, mas que não anulava a arbitrariedade e a violência desta última. Entretanto, essa ordem paralela podia ser rompida, a qualquer momento, seja por confrontos diretos entre os próprios presos ou entre os presos e os funcionários da prisão. Dentre os tipos de protesto, a escrita foi um dos mais utilizados pelos presos e, dependendo da estratégia sugerida nas cartas, era possível conquistar espaços sem romper com a ordem prisional. O recurso à escrita foi utilizado por presos, letrados ou não, de diferentes condições jurídicas - escravos, libertos e livres -, independentemente do tipo de pena que estivessem cumprindo.
\end{abstract}

Palavras-chave: Presos; Penitenciária; Casa de Prisão com Trabalho; Bahia - História Séc. XIX.

\section{Introdução}

No período de 1830 a 1870, o aparelho prisional de Salvador sofreu transformações significativas em decorrência das reformas que tomaram conta de todo o Império do Brasil nos Oitocentos. ${ }^{1} \mathrm{O}$ deslocamento das cadeias da área urbana para as

- Doutoranda do Programa de Pós-Graduação em História Universidade Federal da Bahia - UFBA - 40210-730 - Salvador - BA Brasil. E-mail: claudiat@ufba.br

HISTÓRIA, São Paulo, 28 (2): 2009 
regiões periféricas da cidade, bem como a implantação de novos regulamentos para as cadeias fizeram parte das medidas tomadas pelas autoridades. ${ }^{2}$ A reforma prisional desviou a atenção dos políticos e estudiosos para o interior das instituições carcerárias, o que resultou numa atuação mais rigorosa da administração dessas instituições. Entretanto, a mais importante das medidas desse projeto foi a construção e a inauguração, em 1861, da primeira penitenciária baiana, que recebeu o nome de Casa de Prisão com Trabalho. ${ }^{3}$ A reforma prisional no Brasil seguiu os passos da França e dos Estados Unidos os quais iniciaram o seu projeto de reforma das prisões no final do século XVIII. ${ }^{4}$ No decorrer do século XIX, outros lugares do mundo também aderiram à reforma prisional, adaptando-a, estrategicamente, à realidade de cada sociedade. ${ }^{5}$ O Brasil foi o primeiro país da América Latina a dar início a reforma prisional e, também, o primeiro a possuir uma penitenciária, a Casa de Correção da Corte, inaugurada em $1852 .^{6}$

É importante destacar que o Brasil, ao tornar-se independente, continuou escravista, o que significa dizer que a construção do Estado nacional brasileiro se deu com base em instituições que se adaptassem a essa realidade. O próprio Código Criminal do Império, promulgado em 1830, influenciou diretamente o funcionamento do sistema prisional brasileiro ao dar continuidade às práticas de punições do período colonial, como a pena de açoites, de galés e de morte, aplicadas a escravos ou homens livres de forma diferenciada. ${ }^{7}$ Essas penas coexistiram com o novo conceito de punição, baseado na privação de liberdade e na reabilitação do criminoso, representado pela prisão com trabalho, aplicada somente para homens livres e libertos. ${ }^{8}$ Vale lembrar que, nem mesmo no berço da reforma prisional - França e Estados Unidos -, a construção das penitenciárias significou uma ruptura com as punições típicas do antigo regime, uma vez que a pena de morte e a deportação continuaram a ser aplicadas. ${ }^{9}$ Porém, repito, no caso do Brasil, essa continuidade estava relacionada à lógica do regime escravista. 
PARA ALÉM DA ORDEM: O COTIDIANO PRISIONAL DA BAHIA...

Num levantamento para o período de 1861 a1865 constatei que os prisioneiros da Casa de Prisão com Trabalho da Bahia eram sua maioria, sentenciados de justiça do sexo masculino, de condição livre e foram denominados de pardos e crioulos. O crime de maior incidência foi o de morte, seguido de furto. ${ }^{10}$ Pelo menos para as próximas duas décadas, não observei variações neste perfil prisional. A penitenciária da Bahia não tinha calabouços nem celas para escravos como acontecia no Rio de Janeiro e São Paulo. Observa-se claramente a preocupação das autoridades baianas em direcionar a nova instituição para a reabilitação de sentenciados a prisão com trabalho, o que significa dizer que se tratava de homens livres ou libertos. No entanto, o número de libertos era bem reduzido, ficando subentendida a preferência por homens livres. ${ }^{11}$ As mulheres sentenciadas, eram remetidas para a penitenciária somente no período de 1861 a 1865, também em pequena proporção numérica. Daí em diante, até o final do século XIX, o destino das presas sentenciadas de justiça foi a Cadeia da Correção. O motivo alegado pelo administrador foi a não-conclusão das obras, que impediu o projeto de separação de homens e mulheres sentenciados. Entende-se que essas mulheres foram privadas do projeto de reabilitação pensado pelos reformadores. ${ }^{12}$

Nas cadeias comuns, o perfil mudou consideravelmente pois além dos sentenciados que cumpriam pena por falta de vaga na penitenciária, encontrava-se uma população carcerária flutuante e diversificada: homens e mulheres de condição escrava, liberta e livre, crioulos, africanos e europeus. Este último grupo, em menor número, era representado principalmente por portugueses e ingleses. ${ }^{13}$ As infrações rotineiras que, geralmente, resultavam em poucos dias de prisão eram brigas, pequenos furtos, embriaguez, batuque ou candomblé, desordem, infração de posturas municipais, entre outras. As cadeias comuns eram também o destino dos escravos depositados pelos seus senhores a fim de serem castigados e, logo depois, devolvidos mediante o pagamento de uma taxa. Todos esses assuntos eu já tratei em outros trabalhos. 
Este artigo tem a intenção de analisar a correspondência de presos endereçada às autoridades baianas. Através dessa documentação, busco entender o espaço prisional a partir da visão dos seus principais personagens, uma vez que o "discurso oficial" tende a omitir a voz e a ação desses homens e mulheres que participaram ativamente na construção da Salvador oitocentista. São documentos que, felizmente, sobreviveram ao desinteresse da instituição prisional em preservar a palavra dos presos e, em muitos casos denunciavam falhas graves de funcionários e autoridades. ${ }^{14}$ É claro que essas cartas tornam-se ainda mais valiosas quando confrontadas com os documentos administrativos, o que enriquece ainda mais a interpretação das questões específicas tratadas em ambos. A escrita foi um meio de protesto bastante utilizado por presos, fossem homens, mulheres, livres, escravos ou libertos, sentenciados ou não. Tratava-se de cartas ou petições individuais e coletivas, que protestavam contra a má alimentação, privação de visitas, violência, falta de tratamento médico, detenções sem motivos, além de cartas que revelam redes complexas de relacionamento dentro da comunidade prisional, estas últimas mais comuns na penitenciária. Embora nem todos os presos fossem letrados, eles buscavam a ajuda de companheiros ou de advogados para servirem de mediadores. No entanto, é significativo o número desses documentos escritos pelos próprios presos.

É importante ressaltar que outras formas de protesto também foram utilizadas pelos presos, confrontos diretos e indiretos. Quando a negociação se esgotava, ou nem tivesse existido, os presos partiam para um enfrentamento mais aberto através das fugas, revoltas, brigas e da insubordinação. Enfim, lançavam mão de ações que, geralmente, resultavam em dura represália por parte da administração ou do próprio chefe de polícia, autoridade máxima na organização policial e prisional da província. $^{15}$ Neste caso, as punições vinham na forma de violência corporal, reclusão em solitárias, privação de visitas, entre outras. Não é por acaso que a documentação demonstra a preferência dos presos pelos meios indiretos de enfrentamento, como o uso da escrita e da simulação de doenças. O uso de 
PARA ALÉM DA ORDEM: O COTIDIANO PRISIONAL DA BAHIA...

estratégias mais sutis nas relações com o poder visava tornar a vida prisional mais suportável.

Para Carlos Aguirre, eram raras as ocasiões em que os presos de Lima, no Peru, confrontavam abertamente a ordem prisional. Segundo o autor, "muitas das investidas dos presos demonstravam uma estratégia de acomodação e [...] pela qual eles tiravam tanta vantagem quanto possível das falhas da administração da prisão". ${ }^{16}$ Uma dessas estratégias, por exemplo, era fingir-se preso de bom comportamento. Segundo Aguirre, o fato do preso parecer aceitar as normas prisionais não quer dizer que ele estivesse satisfeito ou tivesse aceitado sua condição de forma submissa. "Como em tantas outras situações da luta do subordinado com o poder, a aquiescência era claramente uma estratégia para sobreviver e, eventualmente, para sair da prisão, não uma indicação de subserviência ideológica". ${ }^{17}$ Aguirre cita o caso de um prisioneiro conhecido como corneteiro que, devido ao seu comportamento exemplar, tinha autorização para caminhar livremente dentro da prisão e um dia fugiu através do portão principal. Os guardas disseram não saber que Corneteiro era um preso. ${ }^{18}$ Assim como em Lima, existiam presos de "bom comportamento" na Casa de Prisão com Trabalho da Bahia e, nestes casos, eles tinham privilégios como, por exemplo, circular pelo pátio e ficar menos tempo trancado na cela, ou ser escalado para desempenhar algum serviço remunerado nas dependências da prisão. ${ }^{19}$

Aguirre estudou os presos de três instituições prisionais, em Lima, no período de $1850-1945 .^{20} \mathrm{O}$ autor deu ênfase ao mundo dos prisioneiros, buscando entender o cotidiano da vida prisional. No seu estudo sobre a correspondência dos presos percebo algumas similaridades importantes com a penitenciária da Bahia. Refiro-me ao tipo de retórica, principalmente aquela repleta de reverência às autoridades e na qual os presos se apropriavam das idéias da reforma prisional para tentar sensibilizar as autoridades. ${ }^{21}$ Ao trabalhar com as correspondências, Aguirre acentuou as estratégias dos presos no trato com as autoridades visando serem atendidos nas suas reivindicações. Aguirre ainda compara as estratégias 
discursivas do final do século XIX com as das primeiras décadas do século XX, quando o tom subserviente foi substituído por uma retórica mais política. Essa transição coincide com o fim do paternalismo típico do antigo regime. Claro que sua análise está voltada para outro contexto social, cultural e político e, em parte, temporal. Embora eu também me preocupe com as estratégias da escrita, minha proposta central no estudo das cartas baianas é descortinar o cotidiano da comunidade prisional. Essas cartas tiveram o objetivo original de levar até as autoridades os mais variados pedidos e denúncias dos presos. Enquanto documento histórico, elas surgem para o pesquisador como um quebra cabeça que, gradativamente, revelam um mundo difícil de penetrar. Quanto à correspondência administrativa, tenho a dizer que ela é farta, contudo, sem ser confrontada com a dos presos, ela pode se transformar numa muralha que nos impede de enxergar o que realmente interessa: a vida diária do preso.

Antes de prosseguir, gostaria de fazer uma ressalva com relação à questão da resistência no interior da prisão. Acredito ser prudente não interpretar toda ação e discurso dos presos unicamente como resistência, o que poderia reduzir o campo de observação do pesquisador. Michel Brown, em artigo dedicado ao uso exagerado do paradigma da resistência pelos pesquisadores, já advertiu para o perigo da "resistência se unir ao projeto foucaultiano de exploração do poder em todas as suas variações, subterfúgios e disseminações". ${ }^{22}$ Não quero negar com isso as variadas formas de resistência dos presos e de outros grupos subalternos frente aos grupos dominantes, mas apenas chamar a atenção para o perigo das generalizações. Não considerar outras possibilidades - além da resistência - nessas cartas, seria o mesmo que negar o ser humano em nossos personagens.

\section{Correspondências de presos da penitenciária.}

O trecho de uma petição coletiva, endereçada ao presidente da província, é um bom exemplo de como os presos 
costumavam se dirigir às autoridades. O documento foi escrito em 1862 pelo preso João Byspo das Neves, na época com 31 anos, livre, pardo e que cumpria pena por homicídio. ${ }^{23}$ Ao lado de sua assinatura, escreveu "por mim e meus companheiros". ${ }^{24}$ Neves era um preso conhecido pelos médicos no Hospital da Caridade, pois costumava simular doenças sob o pretexto de sair de penitenciária para transitar na cidade. ${ }^{25}$ Esta carta foi endereçada ao presidente da província, Joaquim Antão Fernandes de Leão, na ocasião em que este assumiu a administração da província. Tenho observado que os presos se aproveitavam de momentos estratégicos para protestar. É muito comum encontrarmos um maior número de cartas-denúncias endereçadas a presidentes e chefes de polícia que acabavam de assumir os seus cargos.

Lançai, Exmo. Senhor Caridosamente Vossos olhos sobre nos, e vinde socorrer-nos, lembra-vos Ex. Snr. que apesar dos nossos justos ou injustos crimes somos Brasileiros que arrastados por nossas desgraçadas sinas, fomos tirados da sociedade dos homens e vivemos concentrados na enchovia de huma rigorosa Inquisição, e que algum de nos depois de comprida nossas sentenças ainda possamos hum dia ser útil a nossa pátria, e as nossas desamparadas famílias. ${ }^{26}$

A deferência, o reconhecimento do crime, a promessa de reabilitação, o apelo à questão familiar e mesmo o patriotismo faziam parte de uma retórica baseada na ideologia paternalista típica daquele período. O que passaria apenas por bajulação de fato correspondia a uma estratégia dos presos por dentro da ideologia paternalista de dominação das autoridades, neste caso do presidente da província. A chance de as reivindicações serem atendidas fora dessa relação vertical era quase nula e os presos pareciam conhecer muito bem essa estratégia de sobrevivência e manipulação. O contexto em que os presos redigiam a carta também precisa ser observado para entendermos melhor a política paternalista. Mas havia também uma adaptação aos novos ventos ideológicos especificamente soprados na direção 
da reforma penitenciária. Ao declararem que "depois de comprida nossas sentenças ainda possamos hum dia ser útil a nossa pátria, e as nossas desamparadas famílias", os presos estavam a dizer o que as autoridades províncias esperavam ouvir. Afinal o novo conceito de punição implicava a reforma moral do prisioneiro, segundo o método implantado na recéminaugurada Casa de Prisão com Trabalho, símbolo baiano da modernidade prisional. ${ }^{27}$

Os presos também utilizavam a escrita para reclamar de companheiros de infortúnios, indicando conflitos internos que apontam para relações de dominação entre eles o que revela aspectos importantes da vida na prisão. Um desses casos foi uma carta coletiva de presos, endereçada ao presidente da província, em 1872, que pedia providências quanto à presença de um jovem escravo que fora depositado pelo seu senhor na Casa de Prisão com Trabalho. Não era comum a presença de escravos na penitenciária. A carta tinha um estilo de escrita mais direto do que o usual, embora não abrisse mão da deferência.

Os presos da Casa de Prisão com trabalho, pedem a V. Exa. por obra da caridade que faça Sair deste Estabelecimento um espírito maligno de nome Juvencio, Escravo, que se acha aqui depositado por ordem do Senhor Dr. Delegado a pedido do Senhor do referido muleque. Esperamos que V. Exa. nos atenda com Justiça afim de um destes infelizes não acabar nas penas da Lei por causa de um diabo desta ordem que o Seu Senhor o mandou para a Casa penitenciaria por não poder com elle pelas mesmas queixas e o terror do muleque. Perguntamos a V. Exa. se esta Casa é para os Criminosos ou se he também para um precipício desta ordem, que caminha pelos presos sem distinção, os desafia, arroja-lhes qualquer nome injuriosos há, tange pedras, já tem quebrado a cara de diversos presos com pedra, e por último a poucos dias conseguiu [lançou] uma pedra no pé de ouvido do sobrinho do administrador que quase o mata. Portanto Exm. Sr. a maior parte dos presos deste Estabelecimento tem sofrido as maiores angustias e martírios por este muleque a 6 meses sem terem a quem recorrer, e por não poderem mais sofrerem recorrem a V.Exa. e qualquer violência que se der causado por este espírito endiabrado he 
PARA ALÉM DA ORDEM: O COTIDIANO PRISIONAL DA BAHIA...

V.Exa. o cúmplice por consentir em uma Casa penitenciaria um precipício desta ordem. ${ }^{28}$

A argumentação dos presos supõe a existência de um espaço social dentro da comunidade carcerária no qual o escravo Juvencio não fora aceito. A própria política de ocupação da penitenciária, que formou o quadro prisional basicamente com sentenciados de condição jurídica livre, possa ter contribuído para transformar a CPCT num espaço prisional diferenciado daquele da Casa de Correção. Nesta última, existiam presos de toda a natureza, inclusive sempre um bom número de escravos. Essa diferença parecia dar aos presos da penitenciária certo status entre a população carcerária de Salvador. Vejam que os próprios presos deixaram claro que Juvencio não pertencia ao grupo quando questionaram, ironicamente, o presidente da província se a penitenciária era lugar de criminosos ou para "um precipício desta ordem", se referindo a Juvencio. A rejeição pode ser tanto pelo motivo banal da sua prisão em local inadequado, uma vez que ele não era um criminoso, como pela sua condição escrava. Este último seria um motivo saliente da exclusão, segundo se depreende da petição. Vemos a insistência dos peticionários em diabolizar o escravo, pois todos os epítetos, ou a maioria a ele atribuídos, dizem respeito a essa chave retórica: "diabo", "espírito maligno", "espírito endiabrado" e "precipício".

Os presos acusavam Juvêncio de não respeitar as regras de distinção social quando escreveram que ele "caminhava entre os presos sem distinção", e ainda os desafiava, o que reforça a idéia da existência de uma ordem alternativa às normas do regulamento oficial. Carlos Aguirre constatou nas prisões de Lima a construção de uma ordem costumeira na comunidade prisional, à margem dos regulamentos, que foi construída no cotidiano prisional com a anuência de funcionários. ${ }^{29}$ Pawel Moczydlowski chama esta ordem alternativa ou ordem costumeira de hidden life ou vida oculta, enquanto muitos pesquisadores preferem utilizar o termo "organização informal" ou subcultura prisional. Para Moczydlowsdki, a vida oculta da 
prisão é "geralmente formada por três tipos de relações: aquelas entre prisioneiros, aquelas entre prisioneiros e funcionários e aquelas entre os funcionários da prisão. ${ }^{30}$

A petição deixa claro que Juvencio não se submetia à ordem estabelecida pelos presos, pela administração e, segundo a petição, também pelo seu senhor, ou seja, era um rebelde crônico, dentro e fora da prisão. Esse comportamento de Juvencio seria típico dos chamados moleques que viviam nas ruas de Salvador no século XIX "aterrorizando" os habitantes. Walter Fraga investigou os muitos moleques, livres e escravos, que andavam pelas ruas atirando pedras e falando palavrões, seja por divertimento ou em brigas entre eles. Segundo o autor, "as vadiações e peraltices de rua apareciam como um misto de desdém, indiferença, protesto e resistência a um mundo adulto de horizontes limitados". Nem mesmo os homens da lei intimidavam os moleques, pois "apedrejar e vaiar inspetores e guardas-noturnos era um dos divertimentos preferidos pela molecada". Ainda segundo Fraga, esses moleques formavam bandos que eram, muitas vezes, liderados por menores escravos. ${ }^{31}$ Juvêncio provavelmente reproduzia na prisão os costumes de sua vida cotidiana, ou seja, fazendo peraltices para se divertir ou para resistir a qualquer tipo de enquadramento. A petição sugere que os presos não estavam suportando Juvêncio, a ponto de deixar bem claro que algum ato de violência mais sério poderia ocorrer de parte a parte por causa do "moleque", cabendo ao presidente da província a responsabilidade de evitar uma tragédia anunciada. Esse tipo de ameaça dos presos, talvez fosse exagerada porque fazia parte de suas estratégias de negociação junto às autoridades, a quem não interessava que a ordem interna da prisão fosse rompida, muito menos com tragédias.

Outra correspondência coletiva, datada de 10 de junho de 1873, dirigida ao presidente da província, reforça ainda mais as questões discutidas acima com relação à existência de uma ordem alternativa, além de salientar as relações de dominação entre os presos. A carta coletiva, que identifica os seus autores apenas como "dos presos", contém uma denúncia envolvendo 
corrupção entre enfermeiros e presos. Segundo a carta, os três enfermeiros da penitenciária não compareciam ao trabalho e, ilegalmente, recrutavam presos para atuarem como serventes, a fim de cuidarem dos doentes, trabalho que deveria se feito pelos enfermeiros.

Os infelizes presos da Casa de Prisão com trabalho lhe fazem chegar ao distinto conhecimento as calamidades e maltratos que soffrem por esperarem justiça de V. Exa. Reclamamos e pedimos providencia a V. Exa. sobre o abandono que vivem os duentes desta Casa a falta de Infermeiro porque só se conhece estes homens na visita do medico, por não puderem deixar de o acompanhar, o contrário só ouvimos falar em seus nomes em queixas e exclamações. Saiba V. Ex. que os duentes da Infermaria e das Galerias é entregue á presos cerventes, estes mesmos escolhidos, pelos Infermeiros, aquelles presos infami, ladrões que roubão o sol antes de nascer. Estes Saem com o mingao, o chá, bulaxa, dietas, vendem tudo aos sãos e quando o duente se queixão querem mattar como fez o cervente Jose Luis na nossa Galeria hoje as 8 horas com dous duentes porque se queixaram. Como tem um tal Manoel Gavião que é um terror vende um mes de mingau a 5 e 6 pessoas. ${ }^{32}$

As parcerias entre presos e funcionários eram, geralmente, acordos baseados na ilegalidade e com diferentes graus de gravidade. A carta-denúncia revela práticas de agiotagem entre presos e enfermeiros: "Exm. Senhor, não temos Infermeiros só temos uns homens que protejem a quem emprestam dinheiro, tem um [ilegível] de presos [que] são conservados na dieta e bem tratados por proteção do Infermeiro mó, porque não tem com que lhe pagar o que deve". ${ }^{33}$ A atividade de agiotagem dentro da prisão parecia ser comum e o atraso ou falta de pagamento podia gerar conflitos ou alguns privilégios. No caso do enfermeiro, ele parecia compensar o atraso no pagamento proporcionando uma dieta especial para seu credor. Na própria correspondência dos presos consta o despacho do presidente da província, datado de 14 de julho, ordenando que o chefe de polícia fosse informado sobre a denúncia dos presos. No dia 25 
de julho, ao lado do primeiro despacho, o presidente da província encerrou o caso com a seguinte frase: "indeferido em vista das informações". ${ }^{34}$ Não ficou claro o despacho da presidência visto que a carta coletiva tinha mais um caráter denunciatório do que reivindicatório. Infelizmente não obtive mais informações sobre a repercussão desta correspondência entre as autoridades.

Outros casos comprovam a prática da agiotagem na prisão. Um bom exemplo está num pedaço de papel, escrito com sérias dificuldades gramaticais, que indica a preocupação de Zeferino Felippe Cardozo em não esquecer datas importantes como a de sua prisão e de seus dois julgamentos. Anexo à sua "nota diaria", como ele mesmo intitulou, uma espécie de bilhete sugere o seu meio de sobrevivência. Em algumas linhas ele autorizava um tal Severiano a receber sete mil réis referente a três empréstimos e à venda de uma "camisa nova". ${ }^{35}$

Como vimos, as informações analisadas são, na sua maioria, coletadas de correspondências de presos. Dificilmente a documentação administrativa nos levaria tão longe, salvo em situações específicas de conflito entre membros do grupo dominante, neste caso, entre os membros da administração da prisão. Por exemplo, na ocasião em que um funcionário demitido resolveu tornar públicas práticas ilícitas para tentar se livrar de alguma acusação ou se vingar do superior que o demitiu. $\mathrm{O}$ exadministrador da penitenciária, tenente-coronel Manoel Diniz Villas Boas, ao defender-se das denúncias que pesaram sobre ele, resolveu tornar públicas práticas ilegais que ocorriam dentro da CPCT, dentre elas agiotagem entre presos e funcionários. ${ }^{36}$

A baixa remuneração dos funcionários contribuía para que eles se envolvessem em negócios comerciais com os presos. Um exemplo se deu em 10 de maio de 1873. Exatamente um mês antes dos enfermeiros serem denunciados pelos presos, o enfermeiro Francisco Julio Nabuco escreveu ao presidente da província reclamando aumento por achar que o valor de "quinhentos mil réis anuais é sem dúvida diminuto em relação ao trabalho que se acha encarregado". ${ }^{37} \mathrm{O}$ pedido foi negado. Com os guardas a situação não era diferente, geralmente eram 
PARA ALÉM DA ORDEM: O COTIDIANO PRISIONAL DA BAHIA...

homens pobres que exerciam a função sem, ao menos, serem submetidos a um treinamento específico, sendo comum o envolvimento em "negócios" com os presos, como veremos a seguir.

\section{Joaquim Domingos de Prado, o Tibiri}

O caso deste preso, cuja documentação foi um pouco mais generosa, é mais uma evidência de que, apesar de todo o discurso penitenciário, a Casa de Prisão com Trabalho não era um mundo fechado em si, ou seja, os muros da prisão e sua estratégica localização periférica não foram bastante para isolála da dinâmica social da cidade de Salvador. Desta vez trata-se da correspondência assinada pelo preso Joaquim Domingos de Prado, datada de maio de 1872. Este documento fornece fortes indícios de que as transações de negócio dentro da comunidade prisional iam muito mais além do que as práticas de agiotagem e corrupção que vimos há pouco. Joaquim endereçou a correspondência ao então presidente da província, João Antônio de Araujo Freitas Henriques que, em 1862, exerceu o cargo de chefe de polícia da Bahia. Henriques ficou conhecido na historiografia baiana através do estudo de João Reis sobre o sacerdote africano Domingos Sodré, que sofreu perseguição deste chefe de polícia. ${ }^{38}$ Contudo, o preso Joaquim dizia que, "por conhecer o bom fazejo coração de V. Exa [o presidente Henriques] em vista das Graças e caridade que os infelizes tem recebido no curto expasso da Vossa Administração, é a causa do supplicante vir a vossos pés buscar a sua Alta Proticção como Padrinho dos infelizes disprotigido". ${ }^{39} \mathrm{O}$ tom paternalista de Joaquim tinha um propósito um tanto ousado, como veremos adiante.

$\mathrm{Na}$ carta, Joaquim dizia que ele teria comprado "umas obras de côco e madeira de boi em mãos dos seus camaradas" para mandar vendê-las, a fim de conseguir algum dinheiro. Por não conhecer ninguém fora da prisão, Joaquim resolveu pedir ao senhor Balduino José da Silva, guarda penitenciário, para lhe 
indicar alguém a quem vendesse as tais peças. Foi então que Balduino apresentou ao preso uma preta, dizendo ser ela uma pessoa de confiança, pois era sua "Ama de Casa". ${ }^{40}$ Neste mesmo dia, a negra levou parte da mercadoria para vendê-la. $\mathrm{Na}$ semana seguinte, Balduino procurou Joaquim, em companhia da mesma mulher e lhe pagou apenas parte do total referente ao primeiro lote de peças. Alegou que havia necessitado do dinheiro e que em breve ressarciria o preso. Em seguida, convenceu Joaquim a lhe entregar mais peças, as quais foram entregues à negra. Segundo Joaquim, toda essa transação teria sido presenciada pelo Tenente Comandante dos Empregados, que escreveu, a pedido de Balduino, uma espécie de recibo de entrega, no qual constava a lista das peças e seus respectivos valores. Foi a última vez que Joaquim colocou os olhos em Balduino, pois ele pediu demissão e foi trabalhar na "Companhia nova do Comércio". ${ }^{41}$ De fato, em 15 de maio, o chefe de polícia informou ao administrador da prisão sobre o pedido de exoneração de Balduino. ${ }^{42}$

Após terminar a sua versão da história, Joaquim pediu ao presidente Henriques que interviesse e forçasse o ex-empregado a pagar a dívida, embargando-lhe o ordenado. A ousadia de Joaquim está no fato de pedir para Henriques intervir numa atividade proibida, uma vez que, nas palavras do próprio Joaquim, há " na Casa uma ordem do Snr. Dr. Chefe de Policia, que o preso que negociar com Empregado seja castigado". Porém, Joaquim ressaltou que ele "não fez negocio com o empregado, pediu-lhe que como filho da Cidade procurasse uma pessoa". ${ }^{43}$ Joaquim apresentou três pessoas que poderiam atestar sua história, o já citado tenente comandante, o mestre charuteiro que mora "vizinho de parede e meia" com Balduino, que o teria visto vendendo as obras de madeira na sua casa e, por fim, o mestre barbeiro que teria, inclusive, levado um recado de Balduino para Joaquim , "dizendo que se falar em seu nome que não lhe paga as obras". O mestre charuteiro, mencionado por Joaquim era o funcionário responsável pela oficina de charutaria da penitenciária; e o barbeiro era, também, um 
PARA ALÉM DA ORDEM: O COTIDIANO PRISIONAL DA BAHIA...

funcionário cuja obrigatoriedade da contratação constava no regulamento da prisão.

De posse da correspondência de Joaquim, o presidente Henriques Freitas procurou saber do chefe de polícia informações sobre o preso. O chefe de polícia consultou o administrador perguntando se Joaquim tinha ordem para negociar. $^{44}$ Embora eu não tenha localizado a resposta do administrador, acredito que ela foi negativa, pois o chefe de polícia mandou castigar Joaquim mantendo-o por dois dias na solitária em cela escura, castigo previsto no regulamento. $O$ motivo alegado foi que o preso continuava a "negociar, e dirigirse as autoridades reclamando providências para ser indenizado pelas pessoas com quem transige". ${ }^{45} \mathrm{Em}$ quatro de junho, o presidente Henriques despachou a carta de Joaquim dizendo que, "em vista da informação do Dr. Chefe de Policia não tem lugar o que pretende o suplicante". Também não localizei a resposta do chefe de polícia para o Henriques.

Apesar do castigo Joaquim não desistiu. Henriques deixou a presidência naquele mesmo mês de junho e, no seu lugar, assumiu Joaquim Pires de Machado Portela, no dia primeiro de julho. Em agosto, Joaquim enviou correspondência endereçada ao novo presidente Portela pedindo sua intervenção para que Balduino pagasse a dívida. Disse ao então presidente que o antecessor, Henriques Freitas, havia consultado o administrador sobre a sua transação com Balduino e que ele havia confirmado todo o ocorrido. ${ }^{46}$ Como vimos, não foi ao administrador que Henriques consultou e sim o chefe de polícia. Pelo visto, Joaquim continuou a enfrentar as autoridades pois, em novembro, o chefe de polícia pediu para o administrador informações sobre seu comportamento e desde quando cumpria sentença na penitenciária. ${ }^{47} \mathrm{Em}$ dezembro, seguiu-se novo castigo "contra o procedimento do preso", três dias de solitária em cela escura, com a ressalva de que, em caso de reincidência, o castigo deveria ser mais rigoroso. ${ }^{48}$ Entretanto, um acontecimento que antecedeu à primeira petição ao presidente Henriques sugere que o chefe de polícia poderia estar sabendo das atividades de Joaquim. Foi no mês de abril, quando o próprio chefe de polícia 
mandou entregar ao preso setenta mil réis, referente a uma dívida que um tal Cândido José dos Santos tinha com o preso. O chefe de polícia também pediu que Joaquim fizesse um recibo do pagamento. ${ }^{49}$

Joaquim continuou negociando dentro da prisão. Uma correspondência coletiva de presos, datada de 22 de novembro de 1874, denunciava o administrador da penitenciária por tomar dinheiro emprestado nas mãos de vários presos e não honrar a dívida. Entre os credores estava Joaquim Domingos de Prado, a quem o administrador devia setenta e um mil réis. $\mathrm{O}$ motivo da denúncia dos presos era que o administrador oferecia privilégios para os presos credores, como andar solto pelo pátio, trabalhar nas obras do aterro, na oficina de marceneiro com a remuneração de 1.200 réis por dia, trabalhar no refeitório, dentre outras regalias. Entretanto, a carta dizia que Joaquim não aceitava privilégios por conta da dívida e, no lugar disso, "agradecia, dizendo que quer o seo dinheiro e não importa se esta na chave [trancado na cela], quer imbolsar o seu dinheiro como emprestou". A carta dizia que o "senhor administrador immoralmente esta no estabelecimento castigando os presos, os que tem dinheiro para imprestar são garantidos". Os vícios de grafia, como por exemplo, trocar a letra "e" pela letra "i", e a forma como Joaquim se coloca, como o único credor que não usufruiu das regalias, sugere ser ele próprio o autor da carta. Além da questão do dinheiro, a carta denunciava as condições da comida servida aos presos.

Outro - sim a cumida dos presos, quando os cozinheiros dão é tres quatro horas da tarde, os cuzinheiros levão o tempo somente em beberem cachaça e dando cumida aos soldados, a cumida só cachorro pode come-la tudo quanto é porcaria se encontra dentro da cumida, o Snr. Administrador, não pode dar providencia, porque as ordens delle se leva a [ilegível]. Pedimos a V.Exa. providencia sobre a cuzinha fazendo mudar similhantes cozinheiros porque o Snr. Administrador não tem mais força na casa todos os presos e Empregados sabe que o Snr. Administrador alguma força que tinha perdeu-a. O Snr. Administrador diz que é de mattar o preso Damasio Alvares dos 
PARA ALÉM DA ORDEM: O COTIDIANO PRISIONAL DA BAHIA...

Santos, na chave e note V. Exa. o motivo, no dia 19 de junho do corrente Damasio Alvares dos Santos, quexando do ex-preso João Ferreira Pinto, um preso protigido do Administrador e por isso o Supplicante pede humildimenti; é entregado do Administrador, e rogo a V. Exa. para tomar na alta consideração se acontecer morrer V. Exa. saber da onde provém sua morte.

Dois dias após a emissão, consta o despacho do presidente, na própria carta, mandando comunicar ao chefe de polícia. Percebe-se em Joaquim, desde o caso com Balduino, uma forte perseverança em receber seu dinheiro. A carta também diz que o culpado dessas transações ilícitas era o administrador que infringiu o artigo do regulamento que proibia as negociações. Joaquim não foi o único preso a solicitar a intervenção das autoridades para receber seu dinheiro. Em 1871, o preso José Fernandes de Souza também negociou com um funcionário e levou o calote. Além de vender "alguns objetos" para José Vieira do Amaral, Souza lhe emprestou dinheiro. Amaral era ajudante do tenente comandante da guarda da Casa de Prisão com Trabalho e, assim como Balduino fez com Joaquim, foi exonerado e não pagou o que devia ao preso Souza, o qual também fez queixa ao presidente Henriques. ${ }^{50}$ Vale dizer que os negócios dentro da prisão fugiam à proibição do regulamento e das autoridades. Numa carta ao chefe de polícia o administrador admite a incapacidade de inibir tais práticas e que os guardas ocultamente pegam dinheiro emprestado dos presos. Por fim, sugere que todo dinheiro encontrado com os presos fosse recolhido ao cofre da prisão, mas não encontrei nenhuma medida neste sentido. ${ }^{51}$

As cartas de Joaquim e, por último, a de Pedro, sinalizam que as relações entre os presos, entre os presos e os funcionários e até entre os funcionários não podem ser entendidas dentro dos padrões convencionais que os discursos oficiais tentam transmitir. Ou seja, tais relacionamentos não seguiam a lógica de uma pirâmide social em que a administração se encontrava no topo, os presos na base e os funcionários entre eles. Efetivamente, não era assim. Já vimos 
que entre os presos existiam várias camadas de hierarquia, elas se entrelaçavam e algumas se sobrepunham a certos funcionários, incluindo o corpo da guarda. Vemos também que os castigos não intimidavam os presos, tampouco contribuíam para transformá-los em indivíduos dóceis e obedientes. Outros casos que tenho me deparado também caminham nesta direção. ${ }^{52}$

Com relação à transação comercial entre Joaquim e Balduino, podemos também inferir que Joaquim interpretou 0 calote do guarda Balduino como sendo mais grave do que a sua infração que foi burlar as normas do regulamento que não permitia nenhum tipo de transação comercial dentro da prisão. $\mathrm{Na}$ outra carta citada, que acredito ter sido escrita por Joaquim, o fato do administrador estar envolvido em negociações ilícitas foi usado para minimizar o erro dos presos negociantes, pois um "superior" deveria dar o exemplo. Para os sociólogos David Matza e Gresham Sykes é comum o infrator desviar o foco da atenção dos seus próprios atos para outra pessoa que, supostamente, deveria estar cumprindo e expressando as normas da sociedade. ${ }^{53}$ Este seria o papel do administrador. Outro ponto a analisar é a crença que Joaquim parecia ter na justiça, a mesma justiça que o mantinha preso e que o castigava cada vez que ele se pronunciava sobre a transação com Balduino. ${ }^{54}$ Vale frisar, também, que não encontrei nenhum comentário do chefe de polícia sobre a transgressão do guarda Balduino que, provavelmente, não fez negócios somente com Joaquim. Assim como Joaquim e Pedro, outros presos buscavam resolver questões pessoais com o chefe de polícia que não tinham nenhuma relação com o motivo de suas prisões. Por exemplo, a presa Maria Benedita, escrava condenada à prisão perpétua, pediu, em 1862, ajuda ao chefe de polícia para encontrar um filho que teria deixado aos cuidados de um mestre de ofício, morador da Lapa. Ela foi atendida e o homem intimado a comparecer à Secretaria de Polícia para dar explicações. ${ }^{55}$ Para Ivan Vellasco, ao contrário do que a historiografia sustentou até a década de 1980, as pessoas pobres buscavam a justiça e acreditavam que teriam seus problemas solucionados, os quais 
PARA ALÉM DA ORDEM: O COTIDIANO PRISIONAL DA BAHIA...

também incluíam pequenas dívidas. Para Vellasco, "o acesso à justiça era, por si, um objetivo crescentemente almejado por aqueles que viviam ou tentavam viver em um acordo básico com regras sociais imperantes". ${ }^{66}$ Ora, e no caso dos presos que já haviam rompido com esse acordo básico? O acesso à justiça não era o objetivo somente de pessoas que pretendiam aceitar as regras do jogo social. Como sugere Vellasco, a decisão das pessoas comuns em procurar a justiça e não resolver os problemas movidos pela paixão e pelos impulsos indica uma "racionalidade que revela noções sobre a ordem coletiva e o papel das instituições em administrá-la". ${ }^{57}$ No caso de Pedro, Joaquim, Benedita e muitos outros presos vemos que a prisão não diminuiu nem anulou a percepção que estas pessoas tinham do que era justo. Esses entendimentos os levavam a lutar por seus direitos, mesmo em assuntos não relacionados diretamente com a sua condenação.

Joaquim não se envolveu apenas em questões comerciais. Ele também se mostrou solidário com seus companheiros. Em 10 de maio de 1873, deram entrada na Casa de Prisão com Trabalho dois forçados, isto é, condenados à pena de galés. Tratava-se de Procópio e o escravo Victor que cumpriam pena no Arsenal da Marinha até que um "mao procedimento" resultou na transferência da dupla para a penitenciária. ${ }^{58}$ Logo após a chegada dos dois presos, Joaquim redigiu uma petição endereçada ao presidente da província, a pedido de Victor. $\mathrm{Na}$ carta Victor se dizia inocente e solicitava seu retorno para a "Ribeira" (Arsenal da Marinha) ou sua transferência para qualquer fortaleza ou quartel. Segundo a petição, Victor foi transferido para a penitenciária apenas por estar acorrentado junto com Procópio, que dera uma "pancada no Feitor do trabalho ou encarregado sem que o supplicante tivesse se involvido nem concorrido para isso, antes proibio o referido Procopio de dar a segunda pancada no homem". ${ }^{59} \mathrm{O}$ pedido foi indeferido, em 15 de maio, conforme o despacho do Palácio da Província. Parece que Joaquim tinha também a fama de dominar as letras, pois a petição foi redigida imediatamente após a chegada de Victor. Primeiramente falei em solidariedade, mas 
nada impede que Joaquim tivesse escrito a carta em troco de algum pagamento. Outra observação a se fazer é que a transferência para a Casa de Prisão com Trabalho funcionava como castigo para os condenados à galés. Eles não suportavam a penitenciária porque permaneciam trancafiados nas celas, diferente da rotina do Arsenal e das fortalezas, onde eram distribuídos para trabalhar nas obras públicas da cidade. $O$ costume dos galés de transitar pela cidade e, de alguma forma, ganhar algum dinheiro para garantir o seu sustento, fazia com que eles resistissem ao isolamento na penitenciária. ${ }^{60}$

Joaquim não marcou presença apenas na penitenciária. Sua vida, antes de ser condenado, foi bastante atribulada e marcada por conflitos com a justiça. Como disse um promotor sobre ele, Joaquim era "notado e conhecido pelos seus crimes". ${ }^{61} \mathrm{O}$ promotor não disse quais eram esses crimes. Joaquim era natural da freguesia de São Gonçalo, termo da cidade de Cachoeira, mas vivia desde 1858 no Arraial da Lapa, na Freguesia de Nossa Senhora da Oliveira dos Campinhos, termo de Santo Amaro, região do Recôncavo baiano. Ali era trabalhador da lavoura de mandioca, mas também disse que vivia de negócios. Declarou saber ler e escrever, era livre, porém sobre sua cor não tive informação. 


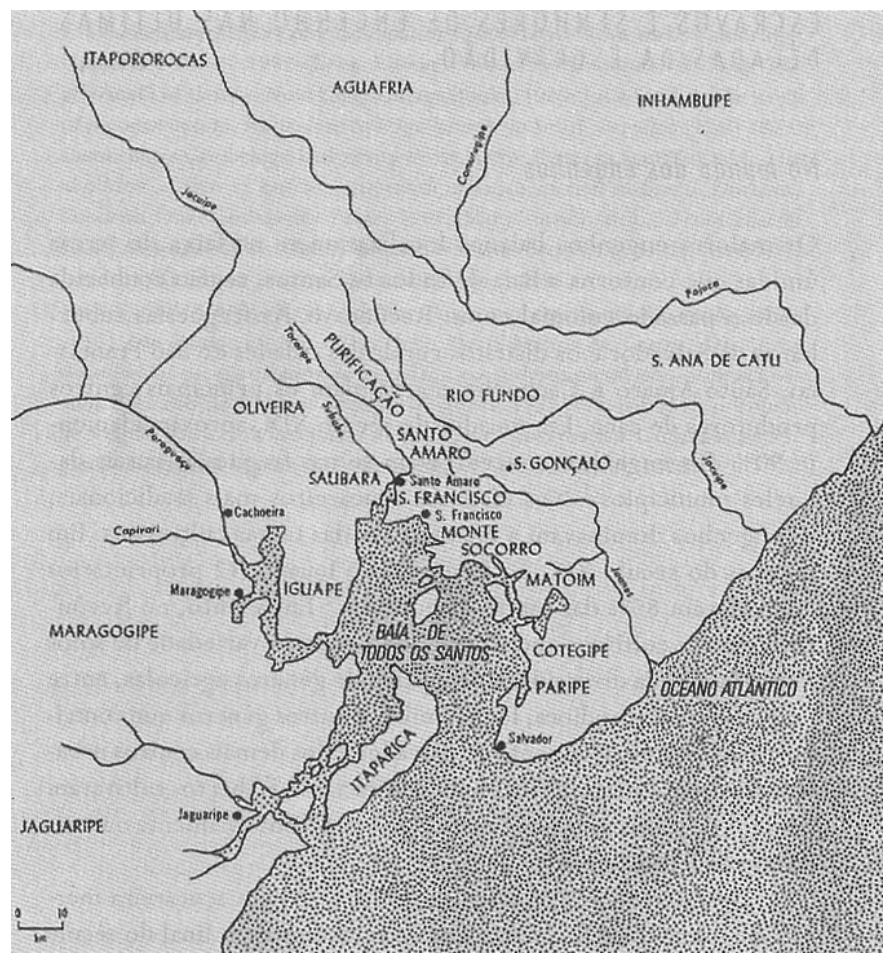

FIGURA 1: Recôncavo baiano: cidades e paróquias.

FONTE: SCHWARTZ, Stuart B. Segredos internos. Engenhos e escravos na sociedade colonial, São Paulo: Companhia das Letras, 1988, p. 84.

$\mathrm{Na}$ época em que escreveu as correspondências na prisão tinha, aproximadamente, 35 anos de idade. Era conhecido por Joaquim Tibiri, filho legítimo de Pedro Domingos de Prado e de Ana Rosa de Jesus. ${ }^{62}$ Também disse ser casado. Tinha um irmão de nome José Pedro Domingos de Prado que foi acusado de defloramento e preso em 1872. Em 1866, Joaquim e seu irmão foram julgados por uma tentativa de homicídio ocorrida em 1858, 
mas foram absolvidos. ${ }^{63}$ Em 1866, foi Joaquim que sofreu uma tentativa de homicídio. Segundo ele, seu tio, conhecido como Cazuza, o feriu com um tiro. O tio teria se comprometido a guardar os "trastes" de Joaquim enquanto este estava preso em Santo Amaro. Conforme Joaquim, o tio vendera tudo sem o seu conhecimento e quando ele saiu da cadeia o tio ficou com receio que ele fosse tirar satisfações e aí atentou contra sua vida. Nada foi provado contra o acusado, que foi absolvido.$^{64}$ Entretanto, não foi nenhum desses conflitos que levou Joaquim à penitenciária para cumprir 16 anos de prisão com trabalho. Em 15 de agosto de 1866 um oficial de justiça, acompanhado de inspetores e guardas, seguiu para o Arraial da Lapa em direção ao sobradinho onde se encontrava Joaquim a fim de cumprirem um mandato de prisão contra ele, que estava em companhia de uma jovem recém "tirada da casa dos paes". Joaquim teria resistido à prisão e, com uma arma de fogo, atingiu um dos inspetores levando-o à morte, além de ferir a dois guardas. Joaquim sempre negou o crime, afirmando que foram os próprios companheiros do inspetor que o mataram. No primeiro julgamento sua condenação foi de galés perpétua, pelos crimes de resistir às ordens das autoridades e por homicídio sem circunstancias agravantes. No crime de morte, foi enquadrado no grau máximo, o que lhe custou a pena de galés perpétua. Joaquim apelou e o tribunal da Relação entendeu que não cabia a sentença e o condenou a duas penas: dois anos de prisão com trabalho pelo crime de resistência e 14 anos de prisão com trabalho por homicídio que desta vez foi considerado de grau médio. ${ }^{65} \mathrm{O}$ fato de Joaquim ter sido condenado por homicídio sem circunstâncias agravantes indica que ele não era reincidente neste tipo de crime. Num de seus interrogatórios Joaquim disse ao Juiz que era um homem de muitos inimigos e parece que ele tinha razão. Em 1883, ele foi morto, de forma brutal, numa emboscada na estrada de Oliveira onde morava. Ao lado do corpo foram encontradas duas armas de fogo e uma faca. Todas as testemunhas, entre elas uma prima de Joaquim de nome Joanna, alegaram não saber sobre o ocorrido, apenas disseram ter ouvido os disparos. ${ }^{66}$ 
PARA ALÉM DA ORDEM: O COTIDIANO PRISIONAL DA BAHIA...

A história de Joaquim é emblemática para demonstrar a riqueza da correspondência de presos, que pode ser utilizada como uma espécie de fio condutor para ultrapassarmos os muros da prisão em busca de fragmentos de histórias de vida dos presos. São pessoas que se destacaram de forma diferente daquelas que por muito tempo chamou a atenção dos pesquisadores. Refiro-me aos personagens considerados vultosos e pertencentes às elites. Felizmente, a historiografia mais recente tem se preocupado com a história de vida das pessoas comuns. ${ }^{67}$ Entretanto, vale dizer que mesmo se tratando de pessoas comuns é preciso que elas tenham se destacado de alguma forma, a ponto de ter gerado documentação suficiente para que seja possível estudá-las. No caso dos presos, a acumulação de documentos está, na maioria das vezes, relacionada à intensidade dos conflitos que eles tiveram com a polícia e com a justiça, como ocorreu no caso de Joaquim.

\section{Regras de convivência entre os presos.}

A violência entre os próprios presos foi outro tema tratado nas correspondências. Como já foi dito, a ordem costumeira, que garantia certa acomodação no ambiente prisional, era efêmera podendo ser rompida a qualquer momento. A violência, por exemplo, nem sempre vinha dos funcionários, pois estava ainda mais presente entre os presos, que dela usavam para resolver questões e demarcar fronteiras. Para alguns autores, a violência praticada pelos presos nada mais é do que uma extensão da vida cotidiana da sociedade mais ampla. ${ }^{68}$ Para a Bahia eu incluiria, nesta sugestão não só a violência, mas outros comportamentos dos presos como, por exemplo, o preconceito contra os escravos, as estratégias de dominação, o comércio e a agiotagem.

Para analisar a questão da violência entre os presos citarei a carta de Braz Antonio Cardoso, endereçada ao Imperador, em 1875, pedindo perdão da sua sentença de doze anos de prisão com trabalho que lhe foi imposta por assassinar outro preso, 
Manoel Francisco Barbosa. Segundo relato de Braz, o preso Manoel era o "homem mais insolente e timido da Casa, que por seus feitos vivia enterrado em um cobico [cela], só lhe abrião a porta de 24 horas acompanhado de guardas Policiais". Braz continuou dizendo que "não satisfeito este insolente homem trazer todos abitantes da Casa de baixo dos pés, no dia sete de março" dirigiu-se a ele, Braz, com "palavras mais orriveis que se pode dizer, e jurando-lhe de dar a resposta pela manha quando lhe abrir-se a porta". No outro dia, Manoel, ao sair da cela, dirigiu-se até onde se encontrava Braz e "descarregou-lhe uma forte pancada com o barril da faxina que trazia na mão". Foi o bastante para que os dois entrassem em luta corporal e, segundo Braz, os outros presos, todos "inimigos capitaes de Manoel", com a desculpa de apartar a briga, se aproveitaram da situação para bater ainda mais neste. Depois da luta apartada teria restado no chão um "cambucú de faca" o qual Braz, imediatamente, se apoderou e feriu mortalmente Manoel. A justificativa foi legitima defesa pois, segundo Braz, se ele não tivesse pego a faca Manoel o faria contra ele. ${ }^{69} \mathrm{~A}$ condenação de Braz também indica que alguns presos ainda cumpriam pena, não por crimes que cometeram fora da prisão, mas dentro dela.

Tomando como mote o ato violento que resultou na morte do preso Manoel, sugiro uma discussão sobre a quebra do código prisional. Ficou evidente que Manoel era hostilizado pelos demais presos, o que supunha a sua não participação na ordem costumeira da prisão, ou que ele teria rompido com ela, talvez por ter violado alguma regra básica que poderia garantir um mínimo de convivência com os presos. ${ }^{70}$ Localizei, até o momento, pelo menos, duas regras que, quando violadas, representavam a quebra do código de convivência. A primeira delas era não ser um informante. O preso que se prestasse a esse papel corria risco de vida dentro prisão. Por exemplo, em 1860, na prisão do Barbalho, o preso Manoel do Nascimento, conhecido por Padre, precisou ser transferido às pressas para a prisão de Galés do Arsenal da Marinha para "evitar o máo futuro que contra elle possa acontecer". O motivo foi ter o referido preso escrito um bilhete para a administração delatando um 
plano de fuga em massa, o que impediu a ação dos presos. Tal comportamento despertou a revolta da população prisional da cadeia do Barbalho, que iniciou uma "sublevação", contida pela ação do chefe de polícia, do carcereiro e de guardas enviados do Arsenal da Marinha especialmente para conter os presos. ${ }^{71}$ Carlos Aguirre assinala que os delatores das prisões de Lima também despertavam a revolta dos presos. Segundo o autor os soplones desempenhavam um papel fundamental na vigilância dos presos, como denunciar planos de fuga, de rebelião, de informar tudo o que se passava entre os presos. Este era um valioso serviço prestado à administração em troca de algum dinheiro ou de privilégios como, por exemplo, ser contratado informalmente para trabalhar na cozinha, na limpeza e até como porteiros. Aguirre cita um exemplo de um preso informante que estava prestes a ganhar liberdade, entretanto ele tinha prevenido a administração sobre um plano de fuga dos presos e, como consequência, passou a ser ameaçado. O resultado foi que o informante passou o restante de sua pena no escritório do diretor da prisão. ${ }^{72}$

Outro comportamento repudiado pelos presos, que tenho visto com frequência na documentação, tem relação com a descrição feita do preso assassinado por Braz. Os presos não suportavam os mais arrogantes e violentos, O caso de espanhol Francisco Panyo ajuda a entendermos essa questão. Em 1842, a enxovia dos homens da cadeia da Relação precisou sofrer alguns reparos e cerca de quarenta presos, que ali se encontravam, foram transferidos, temporariamente, para a Fortaleza do Mar. No retorno à cadeia da Relação, em janeiro de 1843, o carcereiro solicitou que Panyo continuasse isolado na Fortaleza, porque dessa medida dependia o "sossego das prisoens e a tranquilidade dos mais presos". ${ }^{73}$ Uma representação de presos enviada ao chefe de polícia um mês antes de deixarem a Fortaleza do Mar revela o motivo da preocupação do carcereiro em manter Panyo isolado. O preso que assinou a carta em nome dos companheiros dizia que "torna-se o maior perigo possível entre os presos se para as Cadeias [da Relação] vier o perigoso Hespanhol Panyo, pela sua má indole e malvadeza que já teve 
uma vez a arrogancia de insultar e desafiar o Sr. Dr. Delegado encarregado da inspeção das Cadeias". O preso continuou advertindo o chefe de polícia,

Em nome de eu e meus companheiros desejamos o socego na prisão e não desejamos agravar nossos crimes e sentença, o que não acontecerá se para cá elle vier porque a indisposição hé geral e todos estão prevenidos e dispostos, este malvado Exm Snr. está no Forte do Mar em prisão separada pelos seus feitos que já lá tem praticado, e ali mesmo pode ficar até que acabe sua sentença de um ano para ser deportado como V. Sa. ordena pois ele é protestado de fazer um assacinio na prisão para não ser deportado [..] e haja por bem ordenar que aquele malvado homem fique na abobada daquela Fortaleza a bem do socego e da existencia dos supplicantes. ${ }^{74}$

Não estou com isso a generalizar, supondo que todas as formas de violência atuavam como quebra de código prisional. É sabido que a violência era utilizada por presos como instrumento de dominação e símbolo de masculinidade. Neste caso, o preso usaria a violência com o objetivo de conseguir algo, uma violência racional e não aquela usada apenas com o intuito de enfrentar abertamente toda a comunidade prisional. ${ }^{75}$

\section{Correspondências de presos das cadeias comuns.}

Se voltarmos o nosso olhar para as cadeias comuns veremos outro perfil de preso, assim como outro tipo de discursos e de reivindicações. Conforme sinalizado no início deste texto, até 1861 as penas eram cumpridas nas cadeias comuns, onde a herança do aprisionamento colonial era muito mais presente, ou seja, não existia nestas cadeias nenhum projeto de reabilitação como aquele que estava sendo colocado em prática na CPCT. Em 1845, o africano liberto Francisco José Lisboa, preso na Cadeia da Relação, localizada no subsolo da Câmara Municipal, numa atitude corajosa resolveu enfrentar possíveis retaliações ao denunciar que ele havia sido espancado 
PARA ALÉM DA ORDEM: O COTIDIANO PRISIONAL DA BAHIA...

pelo carcereiro. A carta-denúncia, escrita por um procurador de nome Manoel José Marinho da Cunha, dizia ao chefe de polícia que Francisco estava na cadeia da Relação, aguardando o dia de responder a júri, quando foi espancado pelo carcereiro.

aí conta-se que o Carcereiro da mesma cadeia [ da Relação] sem motivo justo o maltratou de pancadas ferindo nas varias [partes do corpo ?] pondo-o finalmente em estado de se não poder levantar e depois de o ter assim maltratado deitou-lhe uma pesada corrente no pescoço para mais do espaço de 24 horas e como o suplicante crime algum cometesse e ao passar o filho deste Carcereiro mandar que o suplicante fosse lançar fora o vazo da servidão daquela prisão e como o suplicante declarasse estar doente acrescendo além disso estar na mesma prisão presos de igual raça a do suplicante quem dispença-se de um tal serviço por motivos de serem mais bem queridos!!! o suplicante miserável e nessa circunstancia que recorre a V. Sa. implorando a inabalavel justiça, mandando que o dito carcereiro responda qual o motivo que o obrigou assim proceder e a vista de sua resposta e do estado em que se acha o supplicante fazendo-se as indagações necessarias do arbitrario procedimento do Carcereiro V. Sa. lhe defira como entender a justiça igualmente pede a V. Sa. lhe mande conduzir ao hospital para ali ser tratado. ${ }^{76}$

O chefe de polícia remeteu a carta ao delegado inspetor das prisões para que este examinasse o estado do preso e tomasse as devidas providências. Essa ordem foi dada no dia 20 de junho e consta que no dia 21 a ordem já havia chegado ao inspetor. Infelizmente não localizei o desfecho da história de Francisco. A existência de uma ordem costumeira na prisão, como já mencionado, não significava uma ordem estável, muito pelo contrário, a qualquer momento ela podia ser quebrada e passaria então a valer a vontade do mais forte. As relações entre presos e funcionários, tanto na penitenciária quanto nas cadeias, eram por si só complexas demais e permeadas de uma tensão constante, o que significa dizer que ela estava sempre prestes a ser rompida, como ocorreu com o africano Francisco que, ao desobedecer a ordem do filho do carcereiro, num ato explícito de 
insubordinação, desafiou o dominante e sofreu as conseqüências do seu ato, rompendo imediatamente com qualquer relação anterior de acomodação (negociação). Neste caso James Scott comenta que "quando, repentinamente, dissipa-se a subserviência e ela é substituída pelo desafio aberto nós encontramos um daqueles momentos perigosos e raros nas relações de poder". ${ }^{77}$ No caso de Francisco o perigo veio na forma de espancamento.

Essa petição alerta para a presença do filho do carcereiro nas dependências da cadeia, assim como a petição sobre o escravo Juvêncio, que discuti há pouco, revelou que o sobrinho do administrador também transitava ou talvez morasse por lá. O regulamento da Casa de Prisão com Trabalho de fato dizia que o administrador e os dez guardas deveriam morar na penitenciária, com a ressalva de que estes últimos deviam ser, de preferência, solteiros ou viúvos. ${ }^{78}$ Quanto ao administrador, não consta nenhum impedimento quanto ao estado civil. ${ }^{79}$

O procurador de Francisco revela o lugar dos presos africanos na cadeia da Relação, ou seja, limpavam os dejetos. A petição também deixa latente a existência de algum tipo de tensão entre Francisco e os outros africanos da cadeia da Relação quando diz que os "presos de igual raça" eram poupados de limpar o vaso de dejetos por serem "mais queridos!!!". Chama também a atenção o estilo irônico e direto do procurador que demonstrou não ter a preocupação com as costumeiras reverências de que se lançava mão ao tratar com o chefe de polícia, cargo geralmente ocupado por homens que já haviam sido juízes de direito e de grande prestígio. O procurador de Francisco, Manoel José Marinho da Cunha, não era um companheiro de prisão, como muitas vezes ocorria, tratava-se de um homem rico, morador de um sobrado na Rua Direita de São Pedro Velho, próximo ao Mosteiro de São Bento. Não encontrei nenhuma informação que justificasse seu envolvimento com o liberto Francisco, como, por exemplo, se ele era seu ex-senhor , seu padrinho ou um advogado. Cunha morreu em 1854, e no seu inventário consta apenas a posse do escravo Tiburcio, cabra, moço, do serviço doméstico, que foi deixado para seu filho de 19 
PARA ALÉM DA ORDEM: O COTIDIANO PRISIONAL DA BAHIA...

anos que estudava Direito em Recife, na época de sua morte. Não localizei seu testamento. Cunha deixou muitas dívidas, indicando a existência de dificuldades financeiras. Neste caso ele poderia ter vendido escravos para saldar dívidas. $\mathrm{Na}$ ocasião do seu inventario, sua casa foi avaliada em oito contos de reis, o equivalente a dez escravos moços, o que pode nos dar uma idéia da sua posição social. ${ }^{80}$

A alta rotatividade era a principal característica das cadeias comuns. Dentro delas foram escritas muitas cartas solicitando soltura. Frequentemente, pessoas inocentes eram colocadas atrás das grades, pois o fato de serem negras fazia com que a polícia as confundisse com escravos em fuga. Nestes casos, o suspeito era levado para a cadeia até comprovar sua condição e, só depois disso, era solto. Muitas vezes a comprovação vinha após o preso ter recebido algum castigo exclusivo para escravos, como palmatoadas ou açoitamento.$^{81} \mathrm{As}$ petições de soltura tinham uma maneira simples e direta de se dirigir à autoridade, bem diferente do tom paternalista utilizado pelos sentenciados. Talvez a falta da retórica paternalista possa estar relacionada ao breve período que estas pessoas ficavam presas. Muitas vezes, era questão de dias apenas para que fossem soltas. Sendo assim, elas não tinham, talvez, a necessidade de tecer relações com as autoridades com o intuito de garantir uma melhor sobrevivência na comunidade prisional, como acontecia com os sentenciados. Dentre esses pedidos de liberdade estava o estranho caso de Manuel Damião de Jesus, preso na cadeia do Aljube, que escreveu ao chefe de polícia dizendo que, no dia 12 de março de 1854, fora detido "pelo simples fato de andar passeando pelas Ruas com huma cobra bixo no pescoço" e por se achar "corrigido desta falta que cometeu" pediu para ser solto. Damião teve seu pedido atendido em apenas três dias. ${ }^{82}$ O Jornal da Bahia não pareceu acreditar na sua inocência e o acusou de tentar tirar "dinheiro dos africanos ignorantes" ao desfilar com a tal cobra no pescoço. ${ }^{83}$

Outra prisão, aparentemente banal foi a de Francisco José da Cunha, que ao escrever sua petição se apresentou como viúvo e com filhos. Cunha relatou que "saindo ontem a tarde de 
sua casa para ir aos seus afazeres na Ordem $3^{a}$ do Carmo onde é Andador, ao passar pela Baixa do Sapateiro ai foi preso por um soldado", sem que ele " tivesse se envolvido em desordem alguma e sim que estava a serviço como consta no documento anexo". O anexo era um atestado assinado por oito moradores da Baixa dos Sapateiros que confirmam a história de Cunha. O chefe de polícia lhe concedeu a "ordem de soltura" no mesmo dia. ${ }^{84}$ Como vemos, muitas pessoas eram presas sem motivo aparente e o fato delas serem soltas após reclamarem sua liberdade reforça essa hipótese. Porém, nem todos eram atendidos, como ocorreu com Thomas da Rocha Barreto que, em 1857, escreveu estar "preso a 56 dias no Aljube sem culpa formada" e que tinha " a necessidade absoluta de ir a sua casa para ali cuidar de arranjos indispensáveis e que precisam de sua presença". O despacho do chefe de polícia se resumiu em três palavras "não tem lugar". ${ }^{85}$

Conforme constatamos, as cartas de presos revelaram-se fontes ideais para conhecermos o cotidiano prisional oitocentista. Vimos que as cartas geralmente foram escritas pelos próprios presos, demonstrando inclusive o grau de letratamento de cada um. Não há dúvida de que essas cartas nos proporcionam uma visão do cotidiano prisional através uma perspectiva muito mais interessante, e por que não dizer, mais "real", do que aquela dos documentos oficiais. Entretanto, são documentos que foram escritos no centro do perigo, utilizando aqui uma expressão de Sidney Chalhoub, e sabemos que diante do poder raramente se fala a verdade. Conforme assinala Chalhoub, o "discurso político dos dominados envolvia a capacidade de atingir objetivos importantes utilizando criativamente - e reforçando, ao menos aparentemente - os rituais associados à própria subordinação". ${ }^{86}$

Vimos também neste artigo que as cadeias e a penitenciária da Bahia oitocentista não devem ser pensadas isoladamente da sociedade mais ampla e sim como parte integrante dela. As transações comerciais que se verificaram dentro da penitenciária, à revelia da administração e das autoridades provinciais, estavam diretamente ligadas às 
práticas sociais, culturais e comerciais do cotidiano da cidade de Salvador. Negros de ganho, ganhadeiras, vendedores, negociantes de toda espécie e até mendigos se apropriavam dos espaços públicos de Salvador, fosse para trabalhos honestos ou transações consideradas ilícitas. Quando algumas dessas pessoas caíam nas malhas da justiça e eram mandadas para a prisão, a tendência era que levassem com elas os elementos que as ajudariam a sobreviver ali dentro. Afinal o ambiente da prisão tendia a reproduzir a lógica da sociedade que o criou. Também fazia parte da experiência das ruas a capacidade de negociação dos presos por liberalidades junto à administração e às autoridades, através dos pedidos de soltura, de denúncias e outros tipos de ação consciente que os ajudavam a suportar melhor a vida na prisão ou livrar-se dela. A rejeição dos companheiros de prisão ao preso escravo, especificamente, refletia preconceitos existentes na sociedade mais ampla. $O$ contexto de onde surgiu a penitenciária brasileira influiu de forma crucial no modelo de sistema penitenciário que se construiu no país ao longo dos tempos. Diante do exposto, resta ao pesquisador do tema valorizar as particularidades da sociedade em que a prisão está inserida e dar menos destaque aos modelos e teorias estrangeiras. Caso contrário, os resultados podem nos levar a interpretações equivocadas, distantes da realidade da qual pretendemos nos aproximar.

\section{Agradecimentos}

Este artigo faz parte de uma pesquisa mais ampla que desenvolvo como doutoranda do PPGH/UFBA sob a orientação do Prof. Dr. João José Reis a quem sou especialmente grata pelos comentários e indicação de fontes documentais e bibliográficas. Agradeço também as sugestões e críticas feitas pelos membros da linha de pesquisa Escravidão e Invenção da Liberdade, do Programa de Pós-Graduação em História da UFBA, e a Prof $^{a}$ Dra. Maria Cecília Velasco e Cruz pelos 
CLÁUDIA MORAES TRINDADE

comentários feitos desde a primeira versão deste artigo. A pesquisa conta com o apoio do CNPq.

\section{Referências Bibliográficas}

\section{Fontes impressas}

BRASIL. COLLEÇÃO das Leis do Império do Brazil. Rio de Janeiro: Typografia Nacional, 1878.

FILGUEIRAS JUNIOR Araujo. Código Criminal do Império do Brazil Annotado, Rio de Janeiro, Eduardo \& Henrique Laemmert, 1876.

Regulamento da Casa de Prisão com Trabalho da Bahia. Aprovado pelo presidente da provincia o conselheiro Antonio Coelho de Sá e Albuquerque em 14 de outubro de 1863, Bahia: Typ. Poggetti - de Tourinho, Dias \& C, 1863, Bahia: Typ. Poggetti, 1863

Resposta apresentada pelo ex-administrador da Casa de Prisão com Trabalho da província da Bahia, tenente-coronel Manoel Diniz Villasboas, no processo de responsabilidade a que foi submentido por acto da presidencia da mesma provincia de 12 de fevereiro de 1868, Bahia: Typographia Constitucional de França Guerra, 1868.

\section{Livros, Artigos e Teses}

AGUIRRE, Carlos. The Criminals of Lima and Their Worlds: The Prison Experience, 1850-1935, Durham, Duke University Press, 2005.

. "Disputed Views of Incarceration in Lima, 1890-1930:

The Prisoners' Agenda for Prison Reform", in Ricardo Salvatore, Carlos Aguirre e Gilbert M. Joseph (orgs), Crime and Punishment in Latin America: Law and society since late colonial times, (London, Duke University, 2001), pp. 342-367.

ALBUQUERQUE NETO, Flávio de Sá Cavalcante de, "A reforma prisional no Recife oitocentista: da Cadeia à Casa de Detenção, 18301874", Dissertação de Mestrado em História, Universidade Federal de Pernambuco, 2008.

ARAÚJO, Carlos Eduardo Moreira de. "Cárceres imperiais: a Casa de Correção do Rio de Janeiro. Seus detentos e o sistema prisional do Império, 1830-1861, Tese de Doutorado em História, Unicamp, 2009.

BROWN, Michel F., On Resisting Resistence", American

Anthropologist, New Series, Vol 98, N 4 (Dec., 1996), pp. 729-735. 
PARA ALÉM DA ORDEM: O COTIDIANO PRISIONAL DA BAHIA...

CHALHOUB, Sidney, "Diálogos políticos em Machado de Assis" in Sidney Chalhoub e Leonardo Affonso de Miranda Pereira (orgs) A História contada: capítulos de história social da literatura no Brasil, Rio de Janeiro, 1988, 95-122.

DIKOTTER Frank e BROWN Ian (orgs), Cultures of Confinement: A History of the Prison in Africa, Asia and Latin America, (Ithaca, New York, Cornell University Press, 2007).

FOUCAULT Michel , Vigiar e punir: história da violência nas prisões, 5. ed. Petrópolis: Vozes, 1987

HOLLOWAY, Thomas H. Polícia no Rio de Janeiro: repressão e resistência numa cidade do século XIX. Rio de Janeiro: Fundação Getúlio Vargas, 1997.

FRAGA FILHO, Walter. Mendigos, moleques e vadios na Bahia do século XIX, Salvador, Hucitec-EDUFAB, 1996.

HOLLOWAY, Thomas H. Polícia no Rio de Janeiro: repressão e resistência numa cidade do século XIX, Rio de Janeiro: Editora Fundação Getúlio Vargas, 1997.

IGNATIEFF, Michael. "Instituições totais e classes trabalhadoras: um balanço crítico", Revista Brasileira de História, 14,(1987), pp. 185-193.

MESSERCHMIDT, James W., "Masculinites, Crime, and Prison", in SABO don , KUPERS Terry e LONDON Willie ( Orgs) Prison Masculinities, (Temple University Press, Philadelphia, 2001), pp. 67-72. MOCZYDLOWSKI, Pawel. The Hidden Life of Polish Prison, Bloomington e Indianapolis: Indiana Universitu Press, 1992.

O'BRIEN, Patricia. "The Prison on the Continent, Europe 1865-1965. In: MORRIS, Norval; Rothman, David J. (orgs), The Oxford History of the Prison. New York: Oxford University Press pp. 178-201.

PAIVA, Helena Marisa Vianna, "A Casa de Correção de Porto Alegre,1889-1898", Dissertação de Mestrado em História Universidade Católica do Rio Grande do Sul, Porto Alegre, 2002.

PERROT, Michele. Os excluídos da história: operários mulheres e prisioneiros, $3^{\mathrm{a}}$ edição, São Paulo, Paz e Terra, 2001

PESSOA, Gláucia Tomaz de Aquino. Trabalho e resistência na penitenciária da Corte 1850-1876, Dissertação (Mestrado em História), Universidade Federal Fluminense, Rio de Janeiro, 2000.

PERROT, Michelle. (org) L'Impossible Prison. Recherches sur le système pénitentiaire au xix ${ }^{\circ}$ siècle, (Éditions Du Seuil, col. L'Univers Historique, 1980). 
REIS, João José, Domingos Sodré: um sacerdote africano, escravidão, liberdade e candomblé na Bahia do século XIX, Companhia das Letras, 2008.

."Domingos Pereira Sodré: um sacerdote africano na Bahia oitocentista", Afro-Ásia, no 34 (2006). . Rebelião escrava no Brasil: a história do levante dos Malês em 1835, Edição Revista e Ampliada. São Paulo, Companhia das Letras, 2003.

ROTHMAN, David J. "Perfecting the Prison, United States, 1789-1865", in Norval Morris e David J. Rothman (orgs) The Oxford History of the Prison. The Practice of Punishment in Western Society (New York, Oxford University Press, 1998), pp.100-116.

SABO don , KUPERS Terry e LONDON Willie, "Gender and the Politics of Punishment", in Sabo, Kupers e London (orgs) Prison Masculinities, (Temple University Press, Philadelphia, 2001), pp. 3-18.

SABO don , KUPERS Terry e LONDON Willie ( Orgs) Prison Masculinities, (Temple University Press, Philadelphia, 2001). SALVATORE, Ricardo, "Penitentiares, Visions of Class, and Export Economies", in Ricardo Salvatore e Carlos Aguirre (orgs), The Birth of the Penitentiary in Latin America: Essays on Criminology, Prison Reform, and Social Control, 1830-1940, (Austin, University of Texas Press, 1996).

SCOTT, James C., Domination and the Arts of Resistance: Hidden Transcripts, New Haven -London, Yale University Press, 1990. SYKES, Gresham M'Gready e MATZA, David, "Técnicas de neutralización: uma teoria de la delincuencia", Caderno CRH, v. 21, n. 52, Jan.Abril de 2008, p. 163-170.

SOARES, Cecília Moreira, "As ganhadeiras: mulher e resistência negra em Salvador no século XIX”, Afro-Ásia, n¹7 (1996).

THOMPSON, E.P. Senhores e caçadores, Rio de Janeiro: Paz e Terra, 1987.

TRINDADE, Cláudia Moraes, A Casa de Prisão com Trabalho da Bahia, 1833-1865. Dissertação (Mestrado em História Social), Universidade Federal da Bahia, Salvador, 2007. ."A reforma prisional na Bahia oitocentista", Revista de História , $\mathrm{n}^{\circ} 158,1^{\circ}$ semestre de 2008, pp. 157-198. . "O nascimento de uma penitenciária: os

primeiros presos da Casa de Prisão com Trabalho da Bahia, 1861-1865", Revista Tempo ( no prelo) 
PARA ALÉM DA ORDEM: O COTIDIANO PRISIONAL DA BAHIA...

VELLASCO, Ivan de Andrade, "Os predicados da ordem: os usos sociais da justiça nas Minas Gerais 1780-1840", Revista Brasileira de História, São Paulo, v. 25, n.50, p. 167-200.

TRINDADE, Cláudia Moraes. Beyond Order: Daily Prison Life in Nineteenth-Century Bahia According to Prisoners' Correspondence. História, v.28, n.2, p.377-420, 2009.

\begin{abstract}
The aim of this article is to discuss the prison community in Bahia during the 19th century, using the correspondence written by prisoners. I analyze this documentation in an attempt to reconstruct the daily life of the prisoners, presupposing the existence of a parallel order equal to or more powerful than the official prison order, but that did not end the arbitrariness and the violence of the latter. This parallel order could be broken any moment, whether because of direct confrontation among the prisoners themselves, or due to confrontation between prisoners and prison staff. Among different types of protest, writing was widely used by prisoners and, depending on the strategy suggested in the letters, it was possible to obtain gains without breaking the prison order. Written appeals were used by prisoners, educated or not, of different legal conditions, slaves, freed and free, independent of the type of sentence they were serving.
\end{abstract}

Keywords: Prisoners; Penitentiary; Prison-workhouse; BahiaHistory 19th Century.

\title{
NOTAS
}

${ }^{1}$ Sobre a reforma prisional na Bahia, ver TRINDADE, Cláudia Moraes. A reforma prisional na Bahia oitocentista, Revista de História, São Paulo, $\mathrm{n}^{\circ} 1581^{\circ}$ semestre, pp. 157-198, 2008; para Pernambuco, ALBUQUERQUE NETO, Flávio de Sá Cavalcanti de. A reforma prisional no Recife oitocentista: da Cadeia à Casa de Detenção (1830-1874). 
CLÁUDIA MORAES TRINDADE

Recife, 2008. Dissertação (Mestrado em História) - UFP; para o Rio de Janeiro ARAÚJO, Carlos Eduardo Moreira de. Cárceres imperiais: a Casa de Correção do Rio de Janeiro. Seus detentos e o sistema prisional do Império, 1830-1861. Campinas, 2009. Tese (Doutorado em História) - Unicamp; para São Paulo, SALLA, Fernando, As prisões de São Paulo: 1822-1940. São Paulo: Anablume, 1999 e para Porto Alegre, ver PAIVA, Helena Marisa Vianna. A Casa de Correção de Porto Alegre, 1889-1898. Porto Alegre, 2002. Dissertação ( Mestrado em História) - PURS.

${ }^{2}$ A reforma do Código de Processo Criminal, em 1841, centralizou na polícia todos os assuntos inerentes as cadeias e a penitenciária inclusive a elaboração dos regulamentos dessas instituições.

3 A instituição foi construída numa área pantanosa localizada "na marinha fronteira ao Engenho da Conceição, pelos fundos da Capela dos Mares". ${ }^{3}$ Este local pertencia à Freguesia da Nossa Senhora da Penha de França de Itapagipe, periferia da Cidade de Salvador. ${ }^{3}$ A partir de 1870, a freguesia da Nossa Senhora da Penha de França de Itapagipe foi desmembrada e o local passou a pertencer à Freguesia de Nossa Senhora dos Mares. Atualmente esta área é conhecida como Baixa do Fiscal e no edifício da antiga Casa de Prisão funciona o Hospital de Tratamento e Custódia do Estado da Bahia. Systema penitenciario. Relatório feito em nome da comissão encarregada, pelo Excelentíssimo senhor Presidente da Província, de examinar as questões relativas a Casa de Prisão com Trabalho da Bahia: Typographia de Galdino Joze Bizerra, e Companhia, 1847, p. 5. Sobre a implantação da Casa de Prisão com Trabalho, ver TRINDADE Cláudia Moraes. A Casa de Prisão com Trabalho da Bahia, 1833-1865, Salvador, 2007. Dissertação (Mestrado em História), PPGH - FFCH, UFBA.

${ }^{4}$ A principal discussão da reforma prisional era substituir as práticas de punições do antigo regime por um novo conceito de punição baseado na reabilitação do infrator, que deveria ser privado da sua liberdade e internado nas instituições penitenciárias. Uma vez isolado do mundo exterior, esperava-se fabricar um novo homem que, entre outras qualidades, estaria pronto para fazer parte do mundo do trabalho e assim ser útil para a sociedade. Sobre este assunto, ver TRINDADE, A reforma prisional..., op. cit. Para uma discussão das doutrinas penitenciárias que fundamentaram a reforma prisional, ver o clássico de FOUCAULT, Michel, Vigiar e punir: história da violência nas prisões, 5. ed. Petrópolis: Vozes, 1987. 
PARA ALÉM DA ORDEM: O COTIDIANO PRISIONAL DA BAHIA...

${ }^{5}$ Sobre a reforma prisional fora da Europa e dos Estados Unidos, ver DIKOTTER, Frank; BROWN Ian (orgs), Cultures of Confinement: A History of the Prison in Africa, Asia and Latin America, (Ithaca, New York, Cornell University Press, 2007).

${ }^{6}$ O Chile e o Peru concluíram suas penitenciárias em 1856. Em 1874 foi a vez do Equador, seguido da Argentina, em 1877. Os últimos países da America Latina a aderirem foram a Colômbia, em 1934, e Cuba, em 1939. AGUIRRE, Carlos. Prison and Prisoners in Modernizing Latin America (1800-1940). In Dikotter; Brown, Cultures of Confinement...,op. cit., pp. 19-20; Sobre Colômbia e Cuba, ver SALVATORE, Ricardo D.; AGUIRRE, Carlos. The Birth of the Penitentiary in Latin America: Toward an Interpretive Social History of Prisons. In: SALVATORE, Ricardo D.; AGUIRRE, Carlos (orgs) The Birth of the Penitentiary in Latin America: Essays on criminology, prison reform, and social control, 1830-1940, (Austin, University of Texas Press, 1996), p. 9.

${ }^{7}$ A pena de açoites era destinada aos escravos. A pena de galés era aplicada a homens livres e escravos, mas, geralmente, para este último grupo. A pena de morte era aplicada em três tipos de crime: homicídio, latrocínio e liderança de insurreição, independente da condição jurídica do infrator.

${ }^{8}$ Sobre a reforma prisional e a legislação brasileira, ver Trindade, "A reforma prisional na Bahia oitocentista". Uma discussão mais aprofundada sobre as penas e os delitos no Código Criminal do Império relacionados com a reforma prisional poder ser vista no trabalho de ALBUQUERQUE NETO. A reforma prisional no Recife oitocentista..., op. cit., pp. 27-51.

9 Ver, por exemplo, a "Mesa redonda de 20 de maio de 1978" onde participaram Michel Foucault, Catherine Duprat, Jacques Leonard, Michellle Perrot, Jacques Revel, Carlo Ginzburg, entre outros. Uma das questões debatidas e apresentadas à Foucault foi a subsistência, na França, no decorrer no século XIX de outros modos de punir (pena de morte, deportação, etc). PERROT, Michelle (org) L'Impossible Prison. Recherches sur le système pénitentiaire au xix ${ }^{0}$ siècle, (Éditions Du Seuil, col. L'Univers Historique, 1980), p. 40. Para os Estados Unidos, ver, entre outros, ROTHMAN, David J. Perfecting the Prison, United States, 1789-1865. In: MORRIS, Norval; ROTHMAN, David J. (orgs) The Oxford History of the Prison. The Practice of Punishment in Western Society (New York, Oxford University Press, 1998), p.100-116 
CLÁUDIA MORAES TRINDADE

${ }^{10}$ TRINDADE, Cláudia Moraes. O nascimento de uma penitenciária: os primeiros presos da Casa de Prisão com Trabalho da Bahia, 1861-1865. Revista Tempo (no prelo). Doravante a Casa de Prisão com Trabalho poderá ser indicada pela sigla CPCT ou simplesmente denominada de penitenciária.

${ }^{11}$ Idem.

${ }^{12}$ Idem.

${ }^{13}$ As cadeias comuns, a que me refiro, são as cadeias civis da Relação (1640/1845), localizada no subsolo da Câmara Municipal de Salvador; cadeia do Aljube (1833-1861), localizada na antiga Ladeira do Aljube, nas imediações onde hoje está o viaduto da Sé, esquina com a Ladeira da Praça; a Casa ou Cadeia da Correção (1832- séc. XX) localizada no Forte de Santo Antônio Além do Carmo; e a cadeia do Barbalho (18451864), localizada no Forte do Barbalho. Por curiosidade, vale destacar que as inúmeras fortalezas na cidade também serviam de prisão militar, geralmente, destinadas a militares e presos políticos. Contudo, algumas delas recebiam presos civis como, por exemplo, "a prisão dos galés" localizada no Arsenal de Marinha e a prisão da fortaleza do Mar. Nas primeiras décadas do século XIX, existiam também os navios prisões, incluindo a Presiganga. Sobre as cadeias de Salvador e a implantação da penitenciária da Bahia, ver TRINDADE. A reforma prisional na Bahia Oitocentista..., op. cit. As mulheres sentenciadas foram aceitas na Casa de Prisão com Trabalho somente no período de 1861 a 1865. O motivo alegado foram as obras incompletas, o que dificultava o projeto de separação de homens e mulheres. Daí em diante, até o final do século XIX, o destino das presas sentenciadas de justiça foi a Casa de Correção.

${ }^{14}$ Michele Perrot destaca que a instituição prisional "recusa a palavra [dos presos] e esconde o escrito, quando não o destrói, nos obscuros arquivos que só podem ser abertos após um século". Para autora esse procedimento seria um dos principais obstáculos para se chegar a vida diária dos presos. PERROT, Michele. Os excluídos da história: operários mulheres e prisioneiros, $3^{a}$ edição, São Paulo: Paz e Terra, 2001, pp.238-239.

${ }^{15}$ Sobre as atribuições do chefe de polícia ver Regulamento $\mathrm{n}^{\circ} 120$ de 31 de janeiro de 1842; Lei $n^{\circ} 361$ de 3 de dezembro de 1841; HOLLOWAY, Thomas H. Polícia no Rio de Janeiro: repressão e resistência numa cidade do século XIX, Rio de Janeiro: Editora Fundação Getúlio Vargas, 1997, p. 158. 
PARA ALÉM DA ORDEM: O COTIDIANO PRISIONAL DA BAHIA...

${ }^{16}$ AGUIRRE, Carlos. The Criminals of Lima and Their Worlds: The Prison Experience, 1850-1935, Durham: Duke University Press, 2005, pp.143-144.

${ }^{17}$ Idem, p. 196.

${ }^{18}$ Idem.

${ }^{19}$ Ver TRINDADE. A Casa de Prisão com Trabalho da Bahia...op. cit., capítulo 4.

${ }^{20}$ AGUIRRE. The Criminals of Lima...op. cit.

${ }^{21}$ Ver o estudo de Aguirre sobre as correspondências de presos. AGUIRRE, Carlos. Disputed Views of Incarceration in Lima, 1890-1930: The Prisoners' Agenda for Prison Reform. In: SALVATORE, Ricardo; AGUIRRE, Carlos; Joseph Gilbert M. (orgs), Crime and Punishment in Latin America: Law and society since late colonial times (London, Duke University Press, 2001), pp. 342-367.

22 BROWN, Michel F. On Resisting Resistence. American Anthropologist, New Series, v. 98, n 4, p.729, Dec.1996.

${ }^{23}$ Relação de presos da Casa de Correção, APEBa, Cadeias, 1857-1861, maço 6271.

24 Mantive a grafia e a pontuação original na transcrição dos documentos de maneira a sugerir ao leitor o grau de letramento dos seus autores. João Byspo das Neves ao presidente da Província, (1862), APEBa, Casa de Prisão, 1836-1868, maço 3082. Sobre as informações pessoais de João das Neves ver Relação de presos da Casa de Correção, APEBa, Cadeias, 1857-1861, maço 6271. O mapa de presos é datado de 1857 onde aparece João das Neves com 26 anos de idade.

${ }^{25}$ Dr. Possivanio Vieira dos Santos ao provedor da Santa Casa de Misericórdia da Bahia, 04/12/1860; João Byspo das Neves ao provedor da Santa Casa de Misericórdia, 1860, Arquivo da Santa Casa de Misericórdia da Bahia (ASMB), Correspondência avulsa do Hospital da Caridade, 1860.

26 João Byspo das Neves ao presidente da Província, (03/1862), APEBa, Casa de Prisão, 1836-1868, maço 3082.

${ }^{27}$ CHALHOUB, Sidney. Diálogos políticos em Machado de Assis. In: Chalhoub, Sidney; Pereira, Leonardo Affonso de Miranda (orgs) A História contada: capítulos de história social da literatura no Brasil, Rio de Janeiro, 1988, 95-122.

${ }^{28}$ Dos presos para o presidente da província, (28/09/1872), APEBa, Casa de Prisão, maço 3084. Grifo do autor.

${ }^{29}$ AGUIRRE, The Criminals of Lima...op. cit., p. 145. 
CLÁUDIA MORAES TRINDADE

30 MOCZYDLOWSKI, Pawel. The Hidden Life of Polish Prisons, Bloomington e Indianapolis: Indiana University Press, 1992, p. xv.

${ }^{31}$ FRAGA FILHO, Walter, Mendigos, moleques e vadios na Bahia do século XIX. Salvador: Hucitec-EDUFAB, 1996, pp.112, 113 e 116.

${ }^{32}$ Dos presos para o presidente da província, 10/05/1873, APEBa, Casa de Prisão, 1872-1874, maço 3084.

${ }^{33}$ Idem.

${ }^{34}$ Idem.

${ }^{35}$ Nota diária do preso Zeferino Felippe Cardozo, APEBa, Casa de Prisão, 1872-1874, maço 3084; Bilhete do preso Zeferino Felippe Cardozo autorizando o senhor Severino a receber dinheiro em seu nome, APEBa, Casa de Prisão, 1872-1874.

${ }^{36}$ Resposta apresentada pelo ex-administrador da Casa de Prisão com Trabalho da província da Bahia, tenente-coronel Manoel Diniz Villasboas, no processo de responsabilidade a que foi submentido por acto da presidencia da mesma provincia de 12 de fevereiro de 1868, Bahia, Typographia Constitucional de França Guerra, 1868, APEBa, Biblioteca.

${ }^{37}$ Francisco Julio Nabuco para o presidente da província, 10/05/1873, APEBa, Casa de Prisão, 1872-1874, maço 3084.

${ }^{38}$ Reis, João José. Domingos Sodré: um sacerdote africano, escravidão, liberdade e candomblé na Bahia do século XIX. São Paulo: Companhia das Letras, 2008, pp. 27-28

${ }^{39}$ Joaquim Domingos de Prado ao presidente da província, maio/1872, APEBa, Casa de Prisão, 1872-1874, maço 3084.

${ }^{40}$ Joaquim Domingos de Prado ao presidente da província, junho/1872, APEBa, Casa de Prisão, 1877-1879, maço 3089.

${ }^{41}$ Joaquim Domingos de Prado ao presidente da província, maio/1872.

42 Secretaria de polícia ao administrador da Casa de Prisão com Trabalho, 15/05/1872, APEBa, Casa de Prisão, maço 5933.

${ }^{43}$ Idem

${ }^{44}$ Chefe de polícia para o administrador da Casa de Prisão com Trabalho, 24/05/1872, APEBa, Casa de Prisão, maço 5933.

45 Chefe de polícia para o administrador da Casa de Prisão com Trabalho, 28/05/1872, APEBa, Casa de Prisão, maço 5934.

46 Joaquim Domingos de Prado para o presidente da província, agosto/1872, APEBa, Casa de Prisão, 1872-1874, maço 3084.

47 Chefe de polícia para o administrador da Casa de Prisão com Trabalho, 11/11/1872, APEBa, Casa de Prisão, maço 5934. 
PARA ALÉM DA ORDEM: O COTIDIANO PRISIONAL DA BAHIA...

${ }^{48}$ Chefe de polícia para o administrador da Casa de Prisão com Trabalho, 13/12/1872, APEBa, Casa de Prisão, maço 5934.

49 Secretaria de polícia ao administrador da Casa de Prisão com Trabalho, 04/04/1872, APEBa, Casa de Prisão, maço 5933.

${ }^{50}$ José Fernandes de Souza para o presidente da província, agosto de 1871, APEBa, Casa de Prisão, 1871, maço 5932.

${ }^{51}$ Administrador interino para o chefe de polícia, 09/02/1972, APEBa, Mapa de presos, 1872-1874, maço 6276.

${ }^{52}$ Ver por exemplo o caso de Francisco Carvalhal em Trindade, "A Casa de Prisão com Trabalho da Bahia", pp. 150-151.

53 SYKES, Gresham M'Gready; MATZA, David. Técnicas de neutralización: una teoria de la delincuencia, Caderno CRH, Salvador, v. 21, n. 52, p. 167, 2008.

${ }^{54}$ Refiro-me aqui a um apelo informal de Joaquim à justiça, pois ele não processou formalmente o seu credor.

${ }_{55}$ Sobre o caso de Benedita, ver TRINDADE. O nascimento de uma penitenciária... op. cit.

${ }^{56}$ Vellasco, Ivan de Andrade. Os predicados da ordem: os usos sociais da justiça nas Minas Gerais, 1780-1840. Revista Brasileira de História, São Paulo, v. 25, n.50, p. 184-185, 2005.

${ }^{57}$ Idem, 184.

58 Administrador da Casa de Prisão com Trabalho para o chefe de polícia, 10/05/1873, APEBa, Mapa de Presos, 1872-1874, maço 6276.

${ }^{59}$ Joaquim Domingos de Prado, a rogo de Victor, para o presidente da província, maio/1873, APEBa, Casa de Prisão, 1847-1889, maço 3087.

${ }^{60}$ Sobre a rotina dos galés ver Trindade, "A reforma prisional na Bahia oitocentista".

${ }^{61}$ Translado Crime de Joaquim Domingos de Prado movido pela Justiça, 1866, APEBa, Seção Judiciária, est. 24 - cx. 859 - doc. 3, fl. 58.

${ }^{62}$ Tentativa de Homicídio, vítima Joaquim Domingos de Prado, 1866, APEBa, Seção Judiciária, est. 15 - cx 535 - doc. 13, fl.4

${ }^{63}$ Tentativa de Homicídio, réus Joaquim Domingos de Prado e José Pedro Domingos de Prado, 1866, APEBa, Seção Judiciária, est.11, cx. 370, doc. 08. A ofício informando a prisão de José de Prado por defloramento se encontra anexo a este processo.

${ }^{64}$ Tentativa de Homicídio, vítima Joaquim Domingos de Prado.

${ }^{65}$ Translado crime de Joaquim Domingos de Prado

${ }^{66}$ Homicídio vítima Joaquim Domingos de Prado, 1883, APEBa, Seção Judiciária, est. 28- cx. 1344 - doc. 7 
${ }^{67}$ Sobre trabalhos de biografia histórica, ver REIS. Domingos Sodré: um sacerdote africano, escravidão, liberdade e candomblé na Bahia do século XIX...op. cit.; XAVIER, Regina. Religiosidade e escravidão no século XIX: mestre Tito. Porto Alegre: Editora da UFRGS, 2008; VAINFAS, Ronaldo, Traição. Um jesuíta a serviço do Brasil holandês processado pela inquisição. São Paulo: Companhia das Letras, 2008, entre outros.

68 Esta é a visão, por exemplo, de SABO, Don; KUPERS,Terry e LONDON, Willie. Gender and the Politics of Punishment. In: SABO, KUPERS e LONDON (orgs) Prison Masculinities (Temple University Press, Philadelphia, 2001) p.12 e, também, do historiador Carlos Aguirre, ver AGUIRRE. The Criminals of Lima...op. cit, p. 175.

${ }^{69}$ Braz Antonio Cardoso para o Imperador, 08/04/1875, APEBa, Casa de Prisão,

70 Para os sociólogos Sabo, Kuppers e London, que tratam da masculinidade na prisão, o código prisional varia de acordo com as mudanças de valores da sociedade. Eles observam, por exemplo, que no final do século XX o código prisional é muito simples, os presos não aceitavam homossexuais, delatores e jogos de apostas. Os autores sugerem que "o código da prisão é muito familiar para os homens nos Estados Unidos porque ele é parecido com o código masculino que prevalece fora da prisão". O exemplo apresentado por eles é a homofobia, pois a regra geral fora da prisão é "não faça nada que leve os outros a pensar que você é um homossexual'. Observação que ratifica o que já foi dito neste artigo de que a prisão reflete os valores da sociedade mais ampla. Embora eu tenha citado o exemplo do homossexualismo, até o momento a pesquisa encontrou, para o século XIX, apenas um caso de relacionamento amoroso entre presos, que foi relatado por Nina Rodrigues numa ocasião que entrevistou um preso "que esteve amaziado com outro preso" dentro da Casa de Prisão com Trabalho. SABO; KUPERS; LONDON. Gender and the Politics of Punishment... op. cit., p. 10; RODRIGUES, Nina. As raças humanas e a responsabilidade penal no Brazil. Rio de Janeiro: Editora Guanabara, 1894 ( re-impressão disponibilizada em meio digital pela Biblioteca Jurídica do Superior Tribunal de Justiça), pp. 131-133.

${ }^{71}$ Encarregado da Prisão da Galé do Arsenal da Marinha para o chefe de polícia, 08/10/1860, APEBa, Mapa de Presos, maço 6285. Sou grata a João Reis pelo envio deste documento.

${ }^{72}$ Aguirre, The Criminals of Lima and Their Worlds, p. 175, pp. 194-195 
PARA ALÉM DA ORDEM: O COTIDIANO PRISIONAL DA BAHIA...

${ }^{73}$ Carcereiro da Relação para o chefe de polícia, 05/01/1843, APEBa, Cadeias, maço 6269

${ }^{74}$ Representação do preso Ambrósio Correia da Conceição para o chefe de polícia, Dez/1842, APEBa, Cadeias, maço 6269.

${ }^{75}$ Para Sabo, Terry e London o preso dominante é aquele que e conseguem utilizar a violência para alcançar conseguir o que quer e demarcar seu espaço de liderança, SABO; KUPERS; LONDON, Gender and the Politics of Punishment... op. cit., pp. 3-18. Utilizo o termo masculinidade com base no conceito de a James W. Messerchmidt o qual diz que a "masculinidade não é um produto estático ou acabado. Os homens constroem masculinidades em grupos sociais específicos. A situação dos homens nas prisões é um exemplo". Para autor, "embora a masculinidade seja sempre individual e pessoal, formas específicas de masculinidade são permitidas, encorajadas e eficazes, a depender da preferência sexual, da raça e da classe de cada um e da situação social". Ainda conforme o autor na "prisão surgem uma variedade de formas de masculinidade. Existe a traição ( aquele que leva as informações para a administração), os comerciantes ( aqueles que vendem mercadorias dentro da prisão) e os 'gorilas' ( aqueles que usam a violência ou ameaçam de violência em favor dos seus próprios interesses)", MESSERCHMIDT, James W. Masculinites, Crime, and Prison. In: Sabo, Terry e London, Prison Masculinities... op.cit., p. 68.

${ }^{76}$ Manoel José Marinho de Cunha, procurador de Francisco José Lisboa, para o chefe de polícia, junho/1845, APEBa, Relação de Presos, 1838-1858, maço 6283.

${ }^{77}$ SCOTT, James C. Domination and the Arts of Resistance: Hidden Transcripts. New Haven -London: Yale University Press, 1990, p. 6.

${ }^{78}$ Regulamento da Casa de Prisão com Trabalho da Bahia. Aprovado pelo presidente da província o conselheiro Antonio Coelho de Sá e Albuquerque em 14 de outubro de 1863, Typ. Poggetti - de Tourinho, Dias \& C., 1863, p. 14.

${ }^{79}$ Suponho que o costume da família do carcereiro ou do administrador de frequentar ou viver na prisão pode ter perdurado até as primeiras décadas do século XX. Pelo menos para as décadas de 1940 e 50, constatei que o diretor da Casa de Correção do Santo Antônio, chamada nesta época de Casa de Detenção, residia ali com sua família. Neste caso era comum o contato dos filhos do diretor com os presos. "Lembro que a gente subia ali [apontando para um determinado local da antiga Casa de Correção] e se jogava para eles [os presos], dizendo 
que era Tarzan", disse Wilson Zito Spínola, filho de Lafaiete Ferreira Spínola, diretor da Casa de detenção do Santo Antônio no período de 1953 a 1959, em entrevista ao Correio da Bahia. "Forte Singular", Jornal Correio da Bahia, Caderno Reporter, 13/01/2008, p.6

80 Inventário de Manoel José Marinho da Cunha, 1855-1857, APEBa, Seção Judiciária, 04/1667/2137-01. Considerei o valor de um escravo com base no valor da avaliação de Tiburcio que foi de 800 réis.

${ }^{81}$ Sobre a legislação criminal e a escravidão ver, TRINDADE. A reforma prisional na Bahia oitocentista... op. cit. Em trabalho anterior cito o caso de um liberto acusado de furto que, confundido com escravo fugido, foi condenado a pena de açoite e a usar ferro no pescoço por dois anos. Depois que seu ex-senhor comprovou sua liberdade sua pena foi comutada para prisão com trabalho. Trindade, "O nascimento de uma penitenciária".

82 Manuel Damião de Jesus para o chefe de polícia, (agosto/1854), APEBa, Relação de Presos, 1838-1858, maço 6283.

${ }^{83}$ REIS. Domingos Sodré: um sacerdote africano, escravidão, liberdade e candomblé na Bahia do século XIX...op. cit., p. 257.

${ }^{84}$ Francisco José da Cunha para o chefe de polícia, ( março/1854); Moradores da Baixa do Sapateiro para o chefe de polícia, (14/03/1854), APEBa, Relação de Presos, 1838-1858, maço 6283.

85 Thomas da Rocha Barreto ao chefe de polícia, (setembro/1857), APEBa, Relação de Presos, 1838-1858, maço 6283.

${ }^{86}$ CHALHOUB. Diálogos políticos em Machado de Assis... op. cit., p. 99.

Artigo recebido em 08/2009. Aprovado em 11/2009. 